\title{
Narrativas em meio à pandemia: tecendo resistências, pensando metodologias, renovando apostas
}

\author{
Narratives in the middle of the pandemic: building resistance, thinking \\ methodologies, renewing bets
}

Luziane de Assis Ruela Siqueira; Luizane Guedes Mateus; Delani Ferreira dos Santos;

Karoline Mendes Santos; Ketle Silva; Nayara Oliveira Francisco

Universidade Federal do Espírito Santo

\section{RESUMO:}

O presente artigo busca compartilhar experiências inventivas nos caminhos metodológicos de pesquisa, a partir de narrativas. Tecendo percursos atravessados pela violência, pela cidade, pelo viver apesar da morte e pela pandemia, buscamos compor esta escrita com mulheres que se abriram ao encontro com outras mulheres - escrita, "escrevivências", construção e destruição de lugares - mulheres, mães, pesquisadoras, narradoras. Diálogos, narrativas, cuidado; autoras e narradoras vivenciando o contexto de pandemia, isolamento e morte, apostamos nas narrativas como afirmação de pesquisas impregnadas de vida, tecidas na arte do encontro, da escuta e dos olhares sensíveis.

Palavras-chave: narrativas; escrevivências; metodologias

\begin{abstract}
:
This article seeks to share inventive experiences in the methodological research paths, based on narratives. Weaving paths crossed by violence, by the city, by living in spite of death and by the pandemic, we seek to compose this writing with women who opened themselves to the encounter with other women - writing, "escrevivências", construction and destruction of places - women, mothers, researchers, narrators. Dialogues, narratives, care; authors and narrators experiencing the context of pandemic, isolation and death, we bet on narratives as an affirmation of research impregnated with life, woven into the art of encounter, listening and sensitive eyes.
\end{abstract}

Key-words: narratives; "escrevivências"; methodologies.

DOI: 10.12957/mnemosine.2021.61842

\section{Introdução}

Mais um dia amanhece cinzento. O corpo pede permissão para permanecer na cama, mas as inúmeras reuniões online exigem que, pelo menos ele, esteja na sala, em frente ao computador... da cama para o sofá, do sofá para a escrivaninha, o corpo obedece aos comandos repetidos, milimetricamente executados, para que o gasto de energia seja o menor possível.

Seguimos para o sexto mês de pandemia, mas o corpo ainda não entende que o espaço público não é uma opção, os contatos e afetos não são uma opção. A pandemia da 
Covid-19 parece reviver pensamentos do final do Século XIX e começo do Século XX, de quando os espaços públicos eram considerados "lugares do perigo", das doenças, das mazelas e onde eram instrumentalizados os considerados criminosos.

Não por acaso, é neste período que também fervilham movimentos de resistência e contestação, manifestações não só na Europa, mas também no Brasil; período em que as ruas são palco dos movimentos populares, e que fazem desses espaços, lugares ameaçadores à ordem vigente. Assim, torna-se necessário esvaziá-los, torná-los inertes através do perigo, fomentando o espaço privado como o espaço do cuidado e da proteção.

Nos dias atuais, a pandemia parece esvaziar não só as ruas e os movimentos de resistência, mas especialmente o compartilhamento de afetos resistentes - não mais nos tocamos, não mais nos encontramos nos bares movimentados para partilhar experiências de luta e de prazer, não mais conseguimos coletivizar nossos incômodos... só seguimos, sobrevivendo. É “sobre viver”... Quais metodologias possibilitam mais que a sobrevida?

A escrita não flui... não flui pela não partilha, não flui pela angustiante espera da morte, que nos espreita nos alimentos que possam estar contaminados, no entregador subalternizado pseudoexaltado nas redes sociais, nas mulheres negras, que se acotovelam nos transportes públicos lotados para chegarem em seus locais de trabalho - o conto do vigário dos serviços essenciais! A escrita não flui, engasga, tosse, está febril, parece retirar o pouco de ar que nos habita... seriam sintomas da Covid-19? Olho o relógio, as poucas linhas escritas, a pauta da próxima reunião online, os boletos, que não estão confinados e continuam chegando. Afetos e escrita permanecem em isolamento, em quarentena, distanciamento social. Qual metodologia usar?

Na TV, a mãe de Miguel Otávio chora e relembra a perda do filho, que morreu após cair do $9^{\circ}$ andar de um prédio de luxo no Centro de Recife. Uma mãe empregada doméstica, preta. Meus devaneios vão até as mães de adolescentes e jovens que têm sido sistematicamente exterminados aqui mesmo, no Espírito Santo. Choro com o choro de Mirtes Renata, mãe de Miguel, que descera para passear com os cachorros da família que a empregava, acreditando que seu filho havia ficado em segurança com a "patroa". Choro porque Miguel estava em seu local de trabalho em decorrência da pandemia, de não ter encontrado quem ficasse com a criança naquele dia. Choro lembrando das operações policiais deflagradas em meio também da pandemia... dos corpos que tombam todos os dias. São corpos negros e pobres!

No alto do privilégio (ou do direito que deveria ser garantido a todos?!) do home 
office, lembro de narrativas, das mães que não pude fazer a devolutiva da pesquisa de pós doutorado. Como estariam agora com suas dores? Mães e familiares de atingidos pela violência no período da greve da Polícia Militar, em 2017, no Espírito Santo... mulheres negras que se acotovelam nos transportes públicos a caminho dos serviços ditos essenciais.

As vozes ainda ecoam nos meus ouvidos, os sons que misturam o narrar com dor, mas também com a necessidade de manter filhos, netos, sobrinhos vivos pela narrativa. Contrariando a lógica do silenciamento e do esquecimento, elas contam e recontam histórias que afirmam a memória, narram para quebrar a sequência de silêncios que ainda imperam acerca das mortes no período da greve da Polícia Militar ${ }^{1}$.

Greve da Polícia Militar... iniciamos este texto com uma narrativa de uma das autoras, que traduz nossas inquietações, desassossegos e reflexões. A pesquisa de pósdoutorado percorreu as potentes, mas também obscuras, narrativas de familiares de atingidos pela violência no período da greve da Polícia Militar do Espírito Santo em 2017. Narrativas que desafiam a morte, que produzem modos de existência mesmo onde não mais existe vida.

Para Mbembe, lidamos com a morte, ou melhor, com a necropolítica, há tempos, poder que subjuga a vida ao poder da morte. O autor analisa as formas de poder contemporâneo, que são "formas novas e únicas da existência social, nas quais vastas populações são submetidas a condições de vida que lhes conferem o status de 'mortosvivos" (MBEMBE, 2018a: 71). Morte e extermínio dos corpos negros e indígenas, passado e presente, história e contemporâneo. E isso produz cansaço. Talvez seja isso: um cansaço que habita o corpo e produz uma escrita difícil, que se dá aos poucos, que tomba diante da morte e da violência. Corpos cansados das lutas cotidianas, de tecer as vidas com fios de ferro, como diz Evaristo (2014). Então lidamos com um impasse: escrevemos, com o corpo que temos, juntando cacos de memórias e lampejos de vida, tentando compor uma escrita feita de retalhos? Ou sucumbimos à produção de morte pela pandemia, pelas violências, pelos processos histórico-colonizatórios que insistem em se atualizar no presente?

Como escrever um texto que fala de metodologias em ato quando o corpo não está em ato? Como pensar a continuidade de nossas propostas de pesquisas, todas baseadas na arte do encontro e na experiência de narrar, tecida no diálogo e na escuta sensível? Como pensar pesquisas impregnadas de vida, tecidas ali mesmo onde a vida se dá, nas guerras 
cotidianas, quando nossos corpos habitam a possibilidade da morte? Pesquisas qualitativas que são inundadas por números: quase 124.000 mortes pelo novo coronavírus.

Dialogamos, refletimos e resolvemos escrever. E isto não é algo banal. Nem é uma imposição moral. Escrevemos por uma aposta ética e intransferível de narrar vidas, para resistir principalmente à objetificação dos corpos negros, corpos negros/femininos. Escrevemos e pesquisamos nos lançando na aposta ético-política de fazer resistência à produção de sujeitos infames (FOUCAULT, 2003). Escrita que impele à renovação de nossos corpos-de-pesquisadoras-psis que buscam romper com a produção de um conhecimento científico-neutro, forjado sob olhares e modelos milimetricamente calculados para manter a opressão, a violência, a subjugação dos corpos: conexão perfeita entre capitalismo, poder e ciência. Assim, buscamos neste texto-resistência, compartilhar nossas experiências de pesquisas, nossas trajetórias que buscam produzir conhecimentos impregnados de vidas, lutas, sofrimentos, mas também de resistências e (re)existências. Mas não tomamos nossas pesquisas e propostas de caminhos metodológicos como manuais ou prescrições metodológicas, compartilhamos os autores e as autoras que nos inspiram na invenção de pesquisas conectadas e imundas de vida, na tentativa de inspirar outras criações de caminhos metodológicos. Assim, compartilhamos como construímos narrativas com as pessoas que se dão ao encontro conosco em nossas pesquisas, inspiradas principalmente pela obra-vida de Conceição Evaristo em sua proposta de escrevivências.

\section{História e infames: as narrativas como experiência e arte do encontro}

Vivemos atualmente um contexto de pandemia que cronifica processos de exclusão social históricos. Assim, torna-se necessário acionar a história a fim de desnudar e analisar o que dela se atualiza no presente. Mas não se trata de remontar o passado tal como ele foi, reproduzindo a história oficial. Partimos das reflexões de Benjamin (1994), que critica a concepção historicista/positivista da história. Para o autor, não há historiador neutro, há a visão dos vencedores, e propõe desconstruir a versão oficial dos fatos, pensando assim, na abertura da história, sendo contada a partir do ponto de vista dos vencidos.

Mais do que não nos deixarmos sucumbir pela pretensa neutralidade, buscamos, nas narrativas, o "acervo de toda uma vida" (BENJAMIN, 1994). Para o autor, a narrativa tem origens remotas que correspondem a um tipo de experiência que encontra na 
modernidade sérias dificuldades: "É como se estivéssemos privados de uma faculdade que nos parecia segura e inalienável: a faculdade de intercambiar experiências" (BENJAMIN, 1994: 198).

O narrador figura entre os mestres e os sábios. Ele sabe dar conselhos: não para alguns casos, como o provérbio, mas para muitos casos, como o sábio. Pois pode recorrer ao acervo de toda uma vida (uma vida que não inclui apenas a própria experiência, mas em grande parte a experiência alheia. O narrador assimila à sua substância mais intima aquilo que sabe por ouvir dizer). Seu dom é poder contar sua vida; sua dignidade é contá-la inteira. O narrador é o homem que poderia deixar a luz tênue de sua narração consumir completamente a mecha de sua vida. Daí a atmosfera incomparável que circunda o narrador, em Leskov como em Hauff, em Poe como em Stenvenson. $O$ narrador é a figura na qual o justo se encontra consigo mesmo (BENJAMIN, 1994: 221).

Em diálogo com as reflexões benjaminianas, pensamos o perigo de uma história única, como nos diz Adichie (2019). Perigo que reside em uma versão única, portanto incompleta, da história de certos sujeitos. Abrir-se à escuta é abrir-se a várias versões de histórias, refutando uma única história sobre os sujeitos pesquisados. É dialogando com esses autores e essas reflexões acerca da história de certos sujeitos que compomos nossas pesquisas, na abertura de ouvir as suas histórias de vida, narradas em primeira pessoa. Ressaltamos que não se trata de quaisquer pessoas, nossa aposta se alia à escuta da narrativa dos vencidos, aposta que "é inseparável de uma opção ética, social e política pelas vítimas da opressão e por aqueles que a combatem” (LÖWY, 2005: 159).

Da história dos vencidos, temos a narrativa de Foucault (2003) acerca da vida dos homens infames, sujeitos cujas vidas sem glória, sem registro, indignas de nota, vidas que não deixam marcas. Invisíveis, a não ser quando se confrontavam com o poder, que lançava luz a suas ínfimas existências. Lobo (2008: 17) narra o percurso histórico dos infames no Brasil, vidas "obscuras como milhões de outras que desapareceram e desaparecerão no tempo sem deixar rastro - nenhuma nota de fama, nenhum feito de glória, nenhuma marca de nascimento, apenas o infortúnio de vidas cinzentas para a história". No entanto, com atenção às movimentações ético-transgressoras, este canal de escrita conjunta dá passagem ainda à propostas de interlocução provocativas, a fim de tensionar possíveis binarismos dicotômico-hierárquicos da historiografia da colonialidade, evocada nas narrativas dos ditos "vencidos" em contraponto às narrativas dos autointitulados “vencedores”. Nego Bispo (SANTOS, 2018) afirma: “nós não somos perdedores", será que se tratam de povos "vencidos"? Uma vez que para ele "mesmo que queimem a escrita, não queimam a oralidade, mesmo que queimem os símbolos, não 
queimam os significados, mesmo que queimem os corpos, não queimam a ancestralidade. Porque as nossas imagens também são ancestrais" (SANTOS, 2018: 51).

Santos (2018) produz uma inflexão pertinente ao modo como as narrativas se inscrevem, endossando deslocamentos possíveis, como entre o termo "escravo" enquanto dado objetivo e "escravizado", que evidencia o processo de produção de seres à condição escravocrata, de "vencidos", que pode reiterar a posição de "perdedores". Santos (2015) propõe a estes condenados da terra ${ }^{2}$, a nomeação propositiva de contracolonizadores. Evidenciando não só a posição de resistência ante às imposições coloniais, negando discursos de passividade, mas, ainda, o ato de rompimento narrativo do lugar de confinamento discursivo da derrota fadada a estes.

Infames, vidas sem marcas, sem história, ou melhor, vidas contadas a partir do ponto de vista dos vencedores/colonizadores. No caso do Brasil, vidas contadas a partir do ponto de vista do invasor europeu. História que torna verdade a visão do povo africano como escravo (e não escravizado), homem-mercadoria (MBEMBE, 2018a). Visão do indígena como selvagem, quase humano, cuja vida foi (e é ainda) expropriada. Abrir a história é abrir-se a várias versões, contadas a partir de outros olhares, como vemos com Nego Bispo (SANTOS, 2015) e Krenak (2020). Santos (2015) traz a narrativa da colonização contada a partir de sua vivência como quilombola, expondo a violência, o extermínio da memória, as guerras pelas terras, a negação da ancestralidade e da religiosidade. Krenak (2019) narra a expropriação das terras dos povos originários e principalmente a visão dos indígenas como selvagens, sem alma, quase humanos, comparação que tinha como parâmetro o colonizador branco europeu.

Histórias de vidas infames, vidas que não são tidas como vidas, tomadas como inferiores e não humanas, processos de extermínio históricos que se atualizam e são cronificados com a pandemia ${ }^{3}$.

Além dos processos de exclusão e das desigualdades sociais, temos falado muito que, ao demandar o isolamento social, a pandemia tem impossibilitado as trocas de experiências. Mas será que a ausência de experiência se dá somente a partir do contexto atual? Será que a mediação tecnológica da vida é um fenômeno recente?

Para Benjamin (1994), a modernidade instaura a impossibilidade de narrar as experiências vividas, tomando a vivência dos combatentes que voltavam da guerra e não conseguiam narrar o que havia sido vivido. Gagnebin (1994), no prefácio do livro do autor, salienta que Benjamin trata do enfraquecimento da Erfahrung, entendida como a 
experiência compartilhada que fundava a narrativa antiga, que era passada de pai para filho, em detrimento da Erlebnis, experiência vivida, da ordem do indivíduo, particular e privada. Cada vez mais, o homem foca em si mesmo, em sua intimidade, no seu mundo privado, sem sua própria existência.

Vemos que não é um fenômeno contemporâneo. Para Larrosa (2014), o homem moderno (a partir do advento da modernidade), é incapaz de ter experiência por falta de tempo, excesso de trabalho, de informação e de opinião. Um sujeito em que tudo the passa, tudo o excita, mas nada é tido como um acontecimento, algo que promova uma transformação. O autor propõe que possamos tombar pelos acontecimentos, parando, ouvindo, detendo o nosso olhar e, principalmente, cultivando a arte do encontro. Tremendo desafio para nós: dar-nos ao encontro, suspender a opinião, a razão - e pensar mais devagar. Tecer experiências de escuta e construção de narrativas que somente são possíveis no "entre", no encontro. Para tanto, é imprescindível manter escuta e olhares estéticos, que "rompam com as estereotipias que nos cegam à diversidade da realidade e da vida. [...] que nos permitam reinventar nossos modos de ver, de ouvir, de sentir, de pensar, de viver e conviver" (ZANELLA, 2006: 139).

O convite que aceitamos e que compartilhamos neste texto demanda esses olhares estéticos, uma escuta atenta e sensível (sensibilidade que pode ser traduzida como um não se contentar com o que está dado, que busca ver além), uma busca pela arte do encontro. Convite de ressignificar infâmias e interromper a produção naturalizada de sujeitos infames, a partir do questionamento de Foucault (2003): "Essas vidas, por que não ir escutá-las lá onde, por elas próprias, elas falam?”

Além do questionamento do autor, nos inspiramos na indagação de Spivak (2014): “pode o subalterno falar?” A autora salienta que os considerados subalternos têm fala, mas não são ouvidos, sua voz não é legitimada. A partir dessas reflexões, buscamos tecer narrativas das vidas que se deram ao encontro conosco em nossas pesquisas, menos para descrever tais vidas, o que, entendemos, reifica um certo olhar da diferença como exótica, ou cria uma ideia de catarse e vitimização. Tecemos narrativas mais para afirmá-las, abrindo passagem a narrativas tecidas em primeira pessoa, possibilidade de histórias múltiplas, torção da história única contada e recontada sobre tais vidas.

Assim se constituem as narrativas das cartas escritas em primeira pessoa por mulheres negras com as quais duas das autoras do artigo se encontraram nas pesquisas de iniciação científica. Cartas que dizem da experiência com a gravidez e o encontro com o 
poder médico, que dizem também das relações tecidas com o atendimento clínico em psicologia, no encontro entre a graduanda e as pacientes, encontro que gera cuidado, escuta e reconhecimento. Ao final, carta de uma pesquisadora na encruzilhada, impregnada de afetos produzidos com a escuta e o se deixar afetar.

Neste caminho imerso de apostas que afirmam a vida, nos encontramos com a proposta de escrevivências de Conceição Evaristo, que nos provoca: "é preciso comprometer a vida com a escrita ou é o inverso? Comprometer a escrita com a vida?" (EVARISTO, 2007).

\section{Escrevivências: narrativas de pesquisas}

O desânimo tem nos habitado com mais frequência nesses dias, o corpo parece colapsar a qualquer instante em meio a esse caos instaurado no contexto de covid-19 somado às crises anteriores, o curto intervalo entre as perdas e mortes não nos permite vivenciarmos nossos lutos plenamente, todavia, é imperioso mantermo-nos firmes para nossa sobrevivência enquanto vivenciamos a iminência da morte. É possível a invenção da vida onde há o risco de morte pela covid-19, pela polícia, por suicídio, pela miséria? Como já reiterado acima, nossas pesquisas e escritas são impregnadas de vida, portanto, não há como nos desvencilhar de todos os afetos, desafetos e das emoções suscitadas nesse tempo, os números de milhares de mortes pela covid-19, o desprezo abertamente declarado de políticos e empresários pela vida (vidas infames, precárias), o recrudescimento da violência do Estado. Logo, apostamos na escrevivência como uma estratégia metodológica, porque aprendemos com Conceição Evaristo (2010) que "a escrita e o viver se con(fundem)".

Desse modo, fazemos o uso da escrevivência como um instrumento metodológico porque ela continua sendo ato de resistência e sobrevivência mesmo quando sentimos o corpo colapsar, ela (escrita) nos possibilita encontrar modos de "transpor os revezes e seguir existindo" (SOARES; MACHADO, 2017: 206). Caminhando pelas pistas da tradição literária de Conceição Evaristo, a autora enuncia seu escreviver como "um modo de ferir o silêncio imposto [...] gosto de dizer ainda que a escrita é para mim o movimento de dança-canto que o meu corpo não executa" (2005) e na tessitura dessa escrita-vida "toma-se o lugar da escrita, como direito, assim como se toma o lugar da vida", nesse caso, resistir por meio da escrita também é re(existir), fazemos da escrevivência nossa contranarrativa por entendermos sua função ética, estética e política em legitimar intelectuais negrxs, e contribuir para o protagonismo de suas narrativas próprias. 
A escrevivência, por meio dos seus recursos analíticos-metodológicos de escrita, nos possibilita uma narrativa conectada com a vivência/experiência que é singular, mas, ao ser compartilhada, remete a outras experiências coletivizadas, porque são narrativas interseccionalizadas por raça, classe, gênero e outras intersecções que atravessam a trajetória de vida de demais mulheres negras. Há, portanto, um "comum constituinte [...], quer seja por características compartilhadas através de marcadores sociais, quer seja pela experiência vivenciada, ainda que de posições distintas" (SOARES; MACHADO, 2017: 206).

Escreviver é ensejar epistemologias transgressoras que subvertem a produção de conhecimento dominante, colocando em perspectiva a dicotomia entre subjetividade e objetividade, é efetivamente nos colocarmos no centro do debate, narrando nossas próprias histórias e vivências, em vez de sermos objetos de estudos daqueles que desfrutam do privilégio epistêmico em detrimento de nós. Nesse sentido, a escrevivência apresenta-se como uma ferramenta de inscrição para autodefinição e emancipação de sujeitos que foram postos historicamente à condição de subalternidade, "escrever pressupõe um dinamismo próprio do sujeito da escrita, proporcionando-lhe a sua autoinscrição no interior do mundo [...] se tratando de um ato empreendido por mulheres negras [...] escrever adquire um sentido de insubordinação” (EVARISTO, 2007).

A escrevivência como ferramenta analítica-metodológica, vivenciada como ética de pesquisa, possibilita, na escrita, uma forma de (re)existir. Narramos histórias de vida de mulheres negras não como objetos, tampouco como sujeitas passivas da pesquisa, mas como protagonistas das suas trajetórias e, por meio do recurso poético-literário da escrevivência, buscamos evidenciá-las como potências inventivas.

\section{Sobre narrar para viver, mesmo na morte ${ }^{4}$}

"Uma pessoa só morre quando morre a testemunha" (João Bosco $)^{5}$

Sentadas no meio fio, conversamos; somos quatro mulheres. O sol escaldante faz o suor escorrer pelo rosto; fluxos da vida são sempre inesperados... Sentadas sob o sol, falamos de filhos, sobre a greve da Polícia Militar, sobre mortes. Pesquisadoras, trabalhadoras, mulheres negras - nossos lugares se atravessam em nossos corpos, nossas falas. Grupo intervenção? Espaço de coletivização de narrativas de mulheres que perderam familiares assassinados? A denominação não nos importa, importa-nos uma 
lista que parece nunca ter fim, a lista de mortos no período da greve da Polícia Militar, em fevereiro de 2017.

Corpos, em sua maioria negros, atingidos por uma violência que, segundo algumas narrativas, foi perpetrada pelas próprias forças policiais do Estado. Segundo Davis (2018) violência que, por vezes, é tida no campo das exceções.

Acho que, com frequência, tratamos esses casos como se fossem exceções, como se fossem aberrações. Ao passo que, na realidade, eles acontecem o tempo todo. E presumimos que, ao punir o autor, a justiça terá sido feita. Mesmo quando policiais são indiciados não podemos ter certeza de que a transformação esteja em pauta (DAVIS, 2018: 43).

Narrativas... histórias contadas e recontadas por familiares, sem a intenção de afirmá-las enquanto verdadeiras ou falsas, muito menos revelá-las, visto que nada há para ser revelado. Como o catador de detritos ou sucata, elas reviram as suas memórias, como sacos escondidos pelo Estado, colhem os cacos dessas histórias. A ideia é "apanhar tudo aquilo que é deixado de lado como algo que não tem significação, algo que parece não ter nem importância nem sentido, algo com que a história oficial não sabe o que fazer" (GAGNEBIN, 2006: 54).

História oficial... discurso visto como universal, "que se vangloria de ser a história verdadeira e, portanto, a única certa e, em certos casos, a única possível” (GAGNEBIN, 2006: 40). Contrariando a lógica do silenciamento e dessa história oficial, essas mulheres buscam histórias que afirmem a memória daqueles que foram mortos, que tentem quebrar a sequência de silêncios que ainda imperam acerca das mortes no período da greve da Polícia Militar.

Silêncios quebrados... Em uma de suas obras, intitulada "Lembrar Escrever Esquecer”, Jeanne Marie Gagnebin nos trará algumas análises acerca dos crimes e genocídios nazistas ocorridos nos campos de concentração, em especial Auschwitz. Serão análises que trarão o relato de sobreviventes desses campos e da forma como produziam e elaboravam memória a partir das experiências traumáticas.

Os sobreviventes, aqueles que ficaram e não se afogaram definitivamente, não conseguiam esquecer-se nem que o desejassem. É próprio da experiência traumática essa impossibilidade do esquecimento, essa insistência na repetição. Assim, seu primeiro esforço consistia em tentar dizer o indizivel, numa tentativa de elaboração simbólica do trauma que lhe permitisse continuar a viver e, simultaneamente, numa atitude de testemunha de algo que não podia nem devia ser apagado da memória e da consciência da humanidade (GAGNEBIN, 2006: 99).

Assim parecem ser elaboradas as memórias daqueles que foram atingidos e 
tiveram familiares mortos no período da greve da Polícia Militar, assim como em outros eventos carregados de violência que perpassam a vida nas periferias. A memória é a base de um processo que faz com que as lembranças jamais sejam esquecidas, como também é a forma encontrada de não permitir que o esquecimento seja perpetuado.

A narrativa enquanto metodologia traz à escrita as memórias dessas famílias, do caminhar de mães, irmãs, tias, esposas; familiares de atingidos pela violência que fazem emergir coletivamente as histórias de vida de seus mortos.

Mortos no período da greve, mortos que vão sendo "desenterrados" no percurso das falas; não para perpetuar-se o lugar de vítimas ou algozes - não trabalhamos com as dicotomias produzidas pelo Estado - mas para frear um caminho de precarização da vida. Vidas que, no limiar, são passíveis de eliminação ou, como nos descreve Butler (2015), vidas precárias. Corpos expostos a todo tipo de desumanização, corpos negros e periféricos que pelos quais não é dado o direito ao luto.

Mas narrativas, no contexto dessas mulheres, são como quebra-cabeças, onde o indizível pela morte, pela individualização, ganha conjunto mesmo com suas diferentes peças, abre a possibilidade de pensar não em precariedades, mas em dignidades.

Ferramenta metodológica que não tem como principal objetivo produzir dados, a narrativa irá nos possibilitar compreender modos de funcionamento singulares de vida, mesmo na morte. Mesmo correndo o risco eminente de cairmos em armadilhas e acabarmos por instituir certas formas de viver, existir, lutar, resistir, institucionalizar, buscamos construir outros lugares de existência junto a essas famílias.

\section{Crise com o Método: escrevivendo em $\operatorname{cartas}^{6}$}

“Todas nós falamos de um tempo e lugar específico, de uma realidade e história específica, não há discursos neutros" (KILOMBA, 2019: 58). Na trajetória de pesquisa de iniciação científica, na posição de mulher negra pesquisadora trabalhando com outras mulheres negras, me questionei se seria possível ocupar esse "lugar pesquisadora", tido que nossas experiências, mesmo não sendo idênticas, atravessam um local comum de discurso marginal.

O rompimento da ideia de neutralidade, almejada como uma das apostas éticas do projeto, foi comparecendo ao longo da pesquisa, na qual toda a metodologia, baseada em protocolos de "como se fazer pesquisa", aprendida nos períodos iniciais da graduação, foi se desfazendo no decorrer da iniciação científica, dando lugar a outros modos de pesquisa 
que nunca nos foram ensinados em sala de aula, e que o tempo todo me faziam questionar se tratavam-se de um saber legítimo. Será essa narrativa legítima? Será o falar de mim relevante e científico? Será que a conversa com uma desconhecida em uma festa que me conta da sua experiência é um material válido de pesquisa?

A escrevivência, que era um plano abstrato no início, se tornou algo totalmente operante. As experiências que me eram contadas se montavam como uma colcha de retalhos e eram guardadas dentro de mim quase como relíquias de família, mesmo se tratando inicialmente de pessoas desconhecidas. As histórias não eram dados de pesquisa! E nada naquela escuta era neutro. Seria isso metodologia? Apostei que sim.

A pesquisa foi construída a muitas mãos, histórias, experiências, choros, risos que não caberiam em uma metodologia neutra, linear e fechada. Por isso a aposta na escrevivência como uma forma de atender à demanda de uma epistemologia que inclua o pessoal e o subjetivo como parte do discurso acadêmico (KILOMBA, 2019).

Eu e a protagonista da minha pesquisa nos conhecíamos há pouco mais de dois meses, quando ela resolveu me contar a sua história. Logo depois da conversa, que prefiro nomear como acontecimento (LARROSA, 2014), pois a minha pesquisa tomou outro rumo a partir daquele dia, ela me convidou para visitá-la em sua cidade, dizendo que eu seria muito bem-vinda.

Afirmar essa experiência como um método de pesquisa não seria possível em uma lógica de pesquisa que objetifica o sujeito, estabelece roteiros de perguntas e respostas e pauta uma distância entre pesquisador e campo. A cor da minha pele, como em muitos outros episódios da minha vida, havia chegado antes da pesquisadora, psicóloga, desconhecida, e possibilitou uma mudança de olhar e recolocação da minha escrita durante o projeto.

Entre o que planejei e o que aconteceu, muita coisa mudou. O contexto de pandemia mundial provocado pelos vírus covid-19 impediu que o campo de pesquisa com as puérperas se concretizasse, e o que a priori não tinha o objetivo de compor a pesquisa se tornou o novo caminho do projeto. A carta de Yasmin (protagonista da pesquisa) e a leitura dos contos de Conceição Evaristo foram acontecimentos que promoveram enorme transformação na pesquisa, um processo onde eu, como pesquisadora, encontrei a possibilidade de contar histórias pela via de cartas.

\section{Carta da Yasmin}


"Bom, vim aqui falar sobre duas experiências que passei que foram bem dolorosas em minha vida. Eu nos meus 21 anos, estava bem trabalhando, casada, mas nem pensava no momento em ter filho. Quando de repente descobrir que num vacilo engravidei (pois é existem sim vacilos), mas enfim descobri que teria um filho, confesso que fiquei confusa, várias emoções, foi uma surpresa que no momento não queria, tinha outros planos no pensamento. Mais meu ex marido que na época era meu companheiro, ficou tão feliz que fui acostumando com a ideia e aos poucos fui me adaptando com aquela nova fase.

A ficha caiu mesmo quando escutei coração do bebê e junto comecei sentir um sentimento que não tinha explicação. Quando fiz 14 semanas, comecei a sangrar fui até o hospital e veio a notícia, que tinha perdido o bebê, momento sentir como se tivesse acabado com a alegria da minha vida e eu mal sabia que o pior ainda estava por vir.

O médico ainda me disse que eu tinha cisto no útero e ovário, que ele nem sabia como tinha conseguido engravidar tão fácil, pois aquele problema dificulta a ovulação. Então ele me passou anticoncepcional que eliminava os cistos e iria prevenir a gravidez. Os dias foram passando e eu fui seguindo e me conformando, pois tinha pegado carinho pelo meu bebê. Depois de alguns meses eu fui trocar de remédio, por vontade própria sem orientação médica. E de novo lá estava eu, grávida, foi outro susto, mas fiquei feliz e logo fui ao médico, fiz plano de saúde, queria ter máximo de cuidados nessa gestação.

E começou as fases, enjôo, uma azia insuportável, mas estava super feliz. O amor já era imenso pelo meu filho, nunca tinha acreditado nessas coisas de sentir, mas eu sabia que era um menino.

No quarto mês me deu alívio, pois o risco de aborto tinha praticamente passado, mas o meu obstetra foi bem sincero, me disse que era bem provável que com 7 meses se o cisto atrapalhasse o desenvolvimento do bebê ia ter que tirar ele prematuro e ter os cuidados na UTI, mas isso ia depender de como ia ficar de acordo que ele fosse crescendo, fiquei com medo mais confiante.

Quando fiz 5 meses veio a certeza daquilo que não sabia era um menino, era o meu Heitor ${ }^{7}$, daí comecei comprar as coisinhas bem aproveitar os chutinhos do meu filho. No 6 mês o obstetra pediu pra que na entrasse de licença para não correr risco de nada, fiquei em casa aproveitando cada momento da gestação.

Adiantamos o chá de fraldas, que foi lindo do jeito que eu quis, todas as pessoas que eu amava estava ao meu lado no momento mais especial e importante da minha vida. 
Chegou o sétimo mês fiz todos tipos de ultrassonografia que tinha e o obstetra me disse que até aquele momento o bebê estava ótimo e que nada estava atrapalhando ele, Heitor estava ótimo, saudável e crescendo normalmente, estava perfeito. Que uma vez por semana era pra mim ir no consultório se tivesse indo tudo do jeito que estava, a gestação poderia chegar até as 39 semanas. Eu fiquei super feliz, e aproveitando a gravidez, fiz ensaios, comprei todas as coisinhas dele, montei o berço e não via a hora de ver ele ali dentro do berço, porque sim a gente fica imaginando e sonhando.

Quando chegou no oitavo mês, (37 semanas) quase nove meses, eu estava ali radiante com minha barriga. Na madrugada do dia 16 comecei a sentir umas dores e ir ao banheiro de 3 em 3 minutos, mas para mim era normal pois gravida vai muito ao banheiro, mais ja era eu perdendo líquido.

Quando fui às 05:00 da manhã as dores aumentaram e fui ao hospital, estava com 2 centímetro de dilatação e o médico de plantão do hospital mandou voltar pra casa e ali ele já tinha visto que estava perdendo líquido e mesmo assim me mandou voltar pra casa porque estava com 37 semanas podia esperar. Liguei para consultório do meu obstetra e ele tinha viajado. Passei aquele dia sentindo dor de 1 em 1 hora, e o desconforto enorme. Na madrugada do 17 passei acordada eu e minha mãe, pois ela ficou comigo tempo todo, parecia que estava sentindo contração junto comigo rsrsrs. De manhã já estava cansada e novamente fui para o hospital, escutei o coraçãozinho do Heitor, mais sentia que algo errado estava. E mais uma vez o médico me disse que eu estava ainda com 37 semanas então poderia voltar pra casa mesmo com 3 centímetros de dilatação e que o bebê estava bem, eu ainda falei para ele se não era melhor me internar, ele falou na minha cara que o doutor lá era ele, que estudou pra isso. E lá voltava eu para casa cheia de dor, tomava remédio que ele passou e nada passava (claro eu estava tendo contrações). Passei mais um dia exausta, a dor me tirava até a fome quase não comia. E foi chegando a noite a dor foi aumentando mais e mais parecia que tudo estava quebrando dentro de mim. A dor era de 10 em 10 minutos. Heitor começou a se mexer de uma forma que nunca tinha mexido, não conseguia ficar deitada, sentada não tinha posição que fizesse amenizar, parecia que minha barriga ia rasgar de tanto que ele se mexia, acho que estava pedindo socorro, pois estava morrendo, ali a quase 3 dias sem líquido nenhum, sem oxigênio, ele ficou 40 minutos se mexendo que até me assustou e todos que estavam ao meu redor. Na madrugada as contrações começaram de $2 \mathrm{em}$. Dois minutos e de repente não estava mais dando pausa. Corremos para o hospital pela terceira vez e fui atendida desta vez por uma 
obstetra. A doutora, ela foi tão carinhosa, e cuidadosa com toda aquela situação, ela viu que o coraçãozinho do Heitor não estava batendo, e mesmo assim para não me deixar ainda pior ela se manteve calma. Ela me disse fazer toda força que tivesse para não precisar fazer uma cesárea, pois estava com a dilatação completa, eu já estava fraca foram quase 72 horas sentindo contração. Mas mesmo assim me lembro, que tirei força que eu nem sei da onde foi. E quando Heitor nasceu que eu olhei ele todo roxo, sem chorar ali eu perdi meu chão, as pediatras tentando reanimar ele, mas não deu certo. Meu filho nasceu sem vida, por negligência médica, se aquele primeiro médico tivesse me internado feito cesárea meu filho estaria vivo. Eu jamais vou esquecer o dia 18 de maio de 2017.

Hoje me conformei, mas lembro todos os dias do meu filho. Sigo a minha vida normalmente quase nem falo muito, mas todos os dias penso nele e lembro de todos nos chutes, e o som das batidas do coraçãozinho dele.

Por negligência médica ele não está vivo".

\section{Escrevivências na Clínica Psicológica ${ }^{8}$}

20 de setembro de 2018: encontro Daniela ${ }^{9}$ pela primeira vez. Dia três de setembro, quando aquele encontro ainda reverbera em nós. Dois anos após. Corta. 2020 agora. A continuidade continua. Porque nos exige. A vida continuou. Se fez. Se refez. E seguiu caminhos naqueles traços de um antigo ano e que agora era antigo e novo também.

03 de setembro de 2020: a mensagem no meu aplicativo dizia: "Oi, Delani. Como está você? Eu estou bem. É... Bem, bem mesmo, eu não estou. É que a gente não se encontra neah?... Essa pandemia mudou tudo. Mas eu estou bem. Estou bem sim. Mas é que falta algumas coisas né? É que você sabe como é... faz dois anos que tá rolando né? (o processo terapêutico). Mas é que ainda tem algumas coisas pra acabar. Mas vamos esperar passar, né? Decidi que vou arrumar o meu quarto mas tenho medo de quando acabar essa arrumação, sabe? O que eu vou fazer depois eu ainda não sei. Mas eu tô bem, tá bom? Pensei aqui em continuar o que começamos. Mas na verdade já é uma continuação, né? Aquela coisa de colar e escrever. Depois a gente remarca tá. Bjss”.

E não remarcamos. E provavelmente não remarcaremos pelos próximos indeterminados tempos. Mas a continuidade continua. Porque nos exige. Porque a vida continuou e porque ela se fez e se refez. Agora à distância. Os grupos de estudos, as escritas, os encontros. As relações todas. Tudo isso marcado pelos processos de escrever e escreviver iniciados antes da interrupção do coronavírus. Coletivamente e 
individualmente.

Escrevivência, como já citado no decorrer deste artigo, é um conceito cunhado por Conceição Evaristo em sua dissertação de mestrado em Literatura Comparada na PUC do Rio de Janeiro. Conceição é uma mulher negra que percebeu as marcas da distinção racial em seu próprio corpo, e sendo parte desse universo dessemelhante no interior do Outro revela, em sua escrita, um lugar coletivo. Conceição não se considera uma autora de si mesma, ao contrário disso, provoca-nos como autora de um grupo socialmente marginalizado que compõe. Não por acaso, o termo escrevivência sugere a ideia de uma escrita contaminada com a subjetividade da autora. E dessa mesma forma a escrevivência se fez no espaço da clínica, contaminada das vozes das minhas pacientes.

A proposta das cartas no processo terapêutico foi levada à clínica a partir dessa discussão. Na ocasião, os processos terapêuticos já estavam em andamento quando decidimos construir em conjunto um trabalho de escrevivências (importante salientar que isso só foi possível graças ao processo de pesquisa em iniciação científica). Nesse sentido, buscamos uma metodologia possível à vida, possível à escuta, à sensibilidade, aos relatos e sobretudo às próprias narrativas. Metodologia particular, mas nunca solitária. Metodologia que possibilita, mas não enrijece. Metodologia pensada em conjunto, composta em nosso grupo de estudos, mas também surgida em espontaneidade quando a própria paciente, depois de um ano e meio de trabalho clínico, me afirma "eu quero escrever sobre mim".

Não restavam dúvidas de que aquelas escritas seriam como a busca por um lugar. Lugar de memórias afro-femininas, lugar de memórias afro-brasileiras, lugar de escuta, lugar de fala, lugar de voz. O lugar coletivo de Conceição Evaristo. Era a busca pela ruptura do não lugar. De ambas. Afinal, se de um lado existiam pacientes desejosas de serem ouvidas em sua subjetividade, do outro existia uma pesquisadora que se pretendia também contaminada por todas essas implicações subjetivas dos nossos povos originários.

E assim aconteceu. Foram exatos dez meses de criação. Criamos chão, resistências e cartas. Mas cartas? Cartas. Palavras escritas em primeira pessoa por mulheres negras sedentas por contar as suas histórias. Cartas que descreveram nas suas linhas o cuidado, o afeto e o acolhimento. Cartas que descreveram, inclusive, o reconhecimento que um corpo-negro-cuidado sente diante de um corpo-negro-cuidador. Segue abaixo uma carta da paciente citada neste texto e que, decerto, relata um pouco desses primeiros impactos. 


\section{Carta da Daniela}

“Antes de qualquer coisa acho que preciso me situar de como foi chegar até aqui. No primeiro dia cheguei no npa nervosa e desanimada. Tinha começado a terapia com outro psicólogo e foi maravilhoso desde a primeira sessão; eu estava com medo de que a nova psicóloga não fosse como ele e irritada dele ter me encaminhado pra ela 'só' porque ela também era negra. uma pessoa branca não poderia me atender? meu problema não era a minha cor. Bom, cheguei e ela veio a recepção me chamar e tive uma boa primeira impressão. Sorriso simpático e voz calma.

Entramos na sala e começamos a sessão com a pergunta de sempre: o que te traz até aqui hoje? Ouvir aquela pergunta me trouxe uma sensação ruim de inconstância, só conseguia pensar que a cada 4 semanas um psicólogo diferente me perguntaria a mesma coisa e eu iria ficar num looping falando da minha avó e da minha vida para um morador da grave vitória novo.

Enquanto ela falava eu ia analisando o jeito de se vestir e se portar, as roupas, o cabelo, o tom de voz. Nada nos aproximava. Eu sei que esse deveria ser um texto e uma análise sobre mim nessa trajetória, mas a terapia também tem participação sua. Pra me sentir à vontade lá, eu precisava me sentir a vontade com você.

Minha primeira leitura foi a que a nova psicóloga era preta que parecia branca da UVV. Era calma demais. Calada demais. Ela não me dava as respostas do que precisava fazer. Eu não me sentia a vontade pra falar e ela parecia não se incomodar com meu silêncio, aquilo definitivamente não ia funcionar. Saí desanimada assim como eu entrei. Mas algo aconteceu para que depois de quase 2 anos eu continuasse aqui. Continua..."

E não continuou. 17 de março foi o último encontro que tive com Daniela. Ainda pretendíamos discorrer um extenso caminho de escrita e de compartilhamento. Entretanto, o contexto da pandemia nos impediu de transcorrer por essa longa estrada. Um impedimento brusco e gélido. Brusco, porque rompeu o que de mais precioso tínhamos: os encontros. Gélido, porque nos convidou novamente para o lugar do silêncio.

A ruptura do silenciamento é o primeiro elemento possível quando uma mulher narra a sua própria história. Foi exatamente esse lugar das palavras que pude encontrar com Daniela no trabalho terapêutico e de escrevivências. Todavia, isso foi quebrado por um cenário que novamente nos quis convidar para o silêncio. Afinal, o contexto de pandemia cronifica, de forma evidente, o silenciamento estrutural das minorias. 
Mas não é só isso. Não foi um fim em si mesmo. Necessário dizer que mesmo o convite para o silêncio já não pode ser o mesmo de antes. Experienciar a escrita de si e do outro é sempre avançar um pouco mais. Inegavelmente foram muitos passos dados nessa construção de identidade, resistência e noções de cuidado. Passos que não voltam atrás, porque escreviver é o exercício de continuar escrevendo nas linhas da vida.

\section{Encruzilhadas metodológicas: rasgos, costuras e cicatrizes ${ }^{10}$}

\section{[Carta sem nome, mas com endereço] ${ }^{11}$}

"Me noto, diante de um emaranhado de linhas escritas que partem de contribuições distintas de seis pesquisadoras à céu aberto, com o teto de suas casas mais frequentemente sobre suas cabeças. Cada linha aqui escrita informa um corpo, cada corpo, outros corpos e uma história própria e pluricomposta. Em cada musculatura, marcas de encontros tatuam acontecimentos, em cada vivência, vozes e vidas que colecionam e cohabitam memórias que insistem em ressoar. Me noto. E ao notar-me escancara-se este corpo que trava e desfalecendo sente fôlego, tônus, direção e energia vital estagnarem, minarem e ansiosamente pedirem passagem e algum contorno. Há escape em corpo atrofiando? O que escapa de um corpo travado? Como dar forma a uma escrita narrada em um corpo paralisado de acúmulos de agitação, que vão entupindo ao tentar vazar? O que cruza as ruas por onde essas mulheres caminham em suas pesquisas? O que liga estas seis trajetórias de pesquisa e de vida? Meu corpo aciona e reativa pontos de memória, que retomam pontos de força em minhas trajetórias. Ao me deparar com o registro aqui escrito, de uma pesquisa que carrega no corpo-pesquisadora, histórias de uma guardiã do luto das mortes de seus bebês, sou lançada aos anos que passei acompanhando mulheres, famílias e equipes multidisciplinares nos setores da Ginecoobstetrícia do "Hospital das Clínicas", durante a graduação. Lembro que uma das enfermeiras estava fazendo mestrado em Psicologia e por isso, apresentava uma urgência maior do que a compreensão da escuta psicológica enquanto um "apaga-incêndio". Eram elas, as enfermeiras, que junto às assistentes sociais, às terapeutas ocupacionais, as fisioterapeutas e fonoaudiólogas, das poucas pessoas que nutria algum respeito ao trabalho de uma psicóloga e de qualquer não médica num contexto hospitalar. Contexto que centraliza a soberania no saber médico, mesmo funcionando sob os ombros e os ouvidos da sustentação do trabalho de enfermeiras e técnicas, que junto às auxiliares de serviços 
gerais e as copeiras, conversavam com as mulheres internadas, uma rede de trabalho muito pra além de suas funções contratuais. Eram elas, majoritariamente mulheres e mulheres negras, historicamente mantenedoras do cuidado, ali, na prestação do serviço de saúde e na maioria das mulheres atendidas na saúde pública. Ali, atendi inúmeras mulheres e famílias pretas, que silenciadas pelo saber médico, contavam suas histórias de dores, violências, lutos e também de afetos e emoções. Ali, acompanhei trajetórias e ouvi tantas histórias. Mas há uma marca que nunca esqueci, a escuta de quem carrega a morte no corpo. Atendi adolescentes, jovens, adultas, idosas, que ao começarem uma prosa relatavam, muitas pela primeira vez, um processo de morte vivida. Sejam elas, naquele momento, por situação de aborto legal, eletivo ou espontâneo, sejam elas adultas e idosas que foram retirar um útero, um câncer de mama ou um mioma e o que vinha à tona, dois, dez ou trinta anos depois, frente à uma desconhecida, eram as mortes que carregavam em silêncio e sem direito de fala e luto. Filhos mortos na barriga, logo depois de nascerem, depois de grandes, pelas mãos da polícia, de problemas cardíacos, de diarreia. Dias atrás uma amiga me disse que "um luto relembra outros lutos", porque agora há mais um atravessamento comum entre nós, jovens negras que perderam os pais. Nós acompanhamos em rememorá-los. Me pergunto, que corpos são estes que carregam tantas mortes, a maioria violentas, como as mães, filhas e esposas, que perderam seus filhos pra violência necropolítica do Estado. São elas, mulheres pretas mantenedoras da memória. Quando estou em campo na pesquisa, a memória das ruas, esteja eu em casa, no terreiro, no samba, na mesa de bar ou em algum consultório, a contação de histórias não para. Mesmo a história oficial silenciando as vozes dos infames, estas histórias são contadas, espalhadas de boca em boca, numa esquina, numa igreja, numa macumba, na memória de uma mãe ou de uma paciente. Que método pode fazer jus à complexidade de narrar vidas? Que método pressupõe uma metodologia que acompanhe trajetórias e histórias arraigadas em corpos rasgados pela dor, que sangram ao falar? Que escrita abarcaria $2 \%$ do que é sentido em um corpo? O próprio método precisa acompanhar as ruas que cruzam uma encruzilhada metodológica. Ao narrar e recontar acontecimentos dos vivos e dos mortos, estamos diante de encruzilhadas. Trata-se da encruzilhada como metodologia, como propõe minha pesquisa. Somos seis, habitando as tensões e os desafios de estar na mira do que acontece no centro de uma encruza. Seis mulheres, pretas, branca, sapatão, mãe, pesquisadoras, desviantes. Seis ruas, seis encruzilhadas de bairros distantes e próximos, desembocando na desventura das encruzas metodológicas. Como fazemos o que 
fazemos? Como cartografar e registrar estas memórias? Como recontamos histórias que não são nossas, mas quase que nos pertencem, me sussurra Conceição Evaristo. Ela, ela que nomeia estas escritas de corpo implicado, que sangram ao transcrever, mas reivindicam suas vozes, firmam o chão em suas histórias e dão passagem ao ímpeto ontológico de narrar o mundo. Ao registro de narrativas memoriais que descrevem algo da ordem do sensível, do sentido, do experimentado, que alinhava e costura, como nesta colcha de retalhos, que é o avesso do avesso de fazeres metodológicos e os desafios das encruzas e seus segredos. A costura de narrativas propicia suturar os rasgos e este entrelace, pode produzir alguma cicatrização. A dor, o amor e a saudade, que rasgam a carne dos corpos que insistem em vigorar de pé. Cada corpo tombado rasga o corpo de quem perdura vivo. Cada morte sentida agrava as mortificações existenciais, aumentadas nas vidas descartáveis. O que quer o corpo que insiste em narrar? Desafogar a vida e a garganta lá onde ela é prisioneira? Dar vazão ao que convoca o desejo a agir? Sustentar o direito à memória e à voz, mesmo daqueles ceifados pela morte? Ante ao desejo perverso de aniquilação total da diferença, corporificada na invenção colonial do outro como ameaça inimiga ou invisível, talvez seja a narração, a escrevivência, uma 'reaposta' constituinte que produza e evidencie a costura de processos de início-meio-início, de vidamorte-vida e tombe, não mais os nossos, mas a aniquilação. Se não há como cooptar a integralidade de um ser que perdura nas vidas que insistem afrontosamente em permanecer vivas, hão de continuar havendo modos perecíveis e potentes de manter pulsante o narrar falado, recitado, cantado e escrito. Cabe à pesquisa e às encruzilhadas metodológicas, reincidir apostas éticas neste segredo que mesmo diante da incidência de morte iminente e efetiva, insiste na vida".

\section{Nota de despedida - ou para não concluir}

Por que e para quem escrevemos este artigo? Escrevemos para as mulheres que nos narraram as suas vidas, para quem nos colocamos a uma escuta que suporta "ficar e ouvir", como nos alerta Gagnebin (2006). A autora, citando o Primo Levi, questiona o ouvinte que se levanta e vai embora, indiferente às narrativas dos sobreviventes da guerra sobre o horror vivido. Nós escolhemos ficar e ouvir, suportando uma escuta que corta nossos corpos, faz tombar, inquieta.

Escrevemos para nós mesmas, para não esquecermos de que os caminhos metodológicos de pesquisa devem passar por nossos corpos, acionando memórias, em 
uma dimensão ético-política do pesquisar.

E escrevemos para vocês, querides leitores, não para que reproduzam nossa proposta de metodologia ou supostamente aprendam algo com este artigo. Escrevemos para que possam estar conosco, para que possamos juntar nossos corpos para o enfrentamento das batalhas cotidianas da vida. Agradecemos o aceite em caminhar conosco na leitura de um "texto em retalhos", tecido às vezes em primeira pessoa singular, às vezes em primeira pessoa plural. Relatos-retalhos de pesquisas de iniciação científica, mestrado e pós-doutorado, relatos-retalhos de mulheres negras mães, jovens, que formam um amálgama de narrativas de vida.

Optamos por deixar que as narrativas hora sussurrem em seus olhos/ouvidos as sutilezas da vida tecida em pequenos gestos de escuta e cuidado, hora gritem os brados de angústia e de dor no enfrentamento da morte e da violência. Sussurros e gritos impregnados de vida. Vidas costuradas com fios de ferro, como as nossas próprias vidas. Pesquisas, metodologias e psicologias que se tecem com os mesmos fios, hora tentando cortá-los, hora se apegando a eles para que lembremos de não esquecer que tecemos pesquisas com vidas, vidas que importam, como sempre nos lembra Adichie, Mariele, Floyd, Miguel...

\section{Referências}

ADICHIE, Chimamanda Ngozi. O perigo de uma história única. São Paulo: Companhia das Letras, 2019.

BENJAMIN, Walter. Magia e técnica, arte e política: ensaios sobre literatura e história da cultura. ROUANET, Sérgio Paulo (Trad.). Obras Escolhidas, vol. 1, 7 ed. São Paulo: Brasiliense, 1994.

BUTLER, Judith. Quadros de guerra: quando a vida é passível de luto? LAMARÃO, Sérgio Lamarão; CUNHA, Arnaldo Marques (Trads.). Rio de Janeiro: Civilização Brasileira, 2015.

DAVIS, Angela. A liberdade é uma luta constante. BARAT, Frank (Org.), CANDIANI, Heci Regina (Trad.). 1 ed. São Paulo: Boitempo, 2018.

EVARISTO, Conceição. Da grafia-desenho de minha mãe, um dos lugares de nascimento de minha escrita. In: ALEXANDRE, Marcos Antônio (Org.). Representações performáticas brasileiras: teorias, práticas e suas interfaces. 1. Mazza, 2007.

EVARISTO, Conceição. Conceição Evaristo por Conceição Evaristo. In: DUARTE, Constância Lima (Org.). Depoimento no I Colóquio de Escritoras Mineiras Poesia, ficção, memória. Anais... Belo Horizonte, FALE/UFMG, 2010. Disponível em <http://www.letras.ufmg.br/literafro/autoras/188-conceicaoevaristo> Acesso em 13 de Set. de 2020.

EVARISTO, Conceição. Gênero e etnia: uma escre(vivência) de dupla face. In: 
MOREIRA, Nadilza Martins de Barros; SCHNEIDER, Liane (Orgs.). Mulheres no mundo: etnia, marginalidade e diáspora. João Pessoa: Ideia, 2005, p. 201-212.

EVARISTO, Conceição. Olhos d'água. Rio de Janeiro: Pallas, 2014.

FOUCAULT, Michel. A vida dos homens infames. In: FOUCAULT, Michel. Estratégia, poder-saber. Ditos e escritos IV. Rio de Janeiro: Forense Universitária, 2003, p. 203-222.

FRAGÃO, Luiza. "Aldir foi mais do que um amigo, ele se confunde com minha própria vida", diz João Bosco. Revista Fórum. 4 de maio de 2020. Disponível em: $<$ https://revistaforum.com.br/cultura/aldir-foi-mais-do-que-um-amigo-ele-seconfunde-com-minha-propria-vida-diz-joao-bosco/> Acesso em: 20 de agosto de 2020.

GAGNEBIN, Jeanne Marie. Prefácio - Walter Benjamin ou a história aberta. In: BENJAMIN, Walter. Magia e técnica, arte e política: ensaios sobre literatura história da cultura. ROUANET, Sérgio Paulo (Trad.). Obras Escolhidas, vol. 1, 7 ed. São Paulo: Brasiliense, 1994, p. 7-19.

GAGNEBIN, Jeanne Marie. Lembrar, escrever, esquecer. São Paulo: Editora 34, 2006.

KILOMBA, Grada. Memórias da plantação: Episódios de racismo cotidiano. Rio de Janeiro: Cobogó. 2019.

KRENAK, Ailton. Ideias para adiar o fim do mundo. São Paulo: Companhia das Letras, 2019.

KRENAK, Ailton. O amanhã não está à venda. São Paulo: Companhia das Letras, 2020.

LARROSA, Jorge. Tremores: escritos sobre a experiência. Belo Horizonte: Autêntica, 2014.

LOBO, Lilia Ferreira. Os infames da história: pobres, escravos e deficientes no Brasil. Rio de Janeiro: Lamparina, 2008.

LÖWY, Michael. Walter Benjamin: aviso de incêndio - uma leitura das teses "Sobre o conceito de história". São Paulo: Boitempo, 2005.

MBEMBE, Achille. A crítica da razão negra. São Paulo: n-1 edições, 2018a.

MBEMBE, Achille. Necropolítica. São Paulo: n-1 edições, 2018b.

NAVARRO, Joel Hirtz do Nascimento; CICILIOTTI, Mayara; SIQUEIRA, Luziane de Assis Ruela; ANDRADE, Maria Angélica Carvalho. Necropolítica da pandemia pela covid-19 no brasil: quem pode morrer? quem está morrendo? quem já nasceu para ser deixado morrer? Scielo Preprints. Versão 1. 2020. DOI: https://doi.org/10.1590/SciELOPreprints.901

SANTOS, Antônio Bispo dos. Colonização, quilombos, modos e significados. Brasília: UnB, 2015.

SANTOS, Antônio Bispo dos. Somos da terra. Revista Piseagrama, $\mathrm{n}^{\mathrm{o}} 12$. Belo Horizonte, 2018, p. 44-51. Disponível em: <https://piseagrama.org/somos-daterra/>. Citado em: 22 de agosto de 2020.

SOARES, Lissandra Vieira; MACHADO, Paula Sandrine. Escrevivências como ferramenta metodológica na produção de conhecimento em Psicologia Social. Psicologia Política, vol. 17, n. 39, 2017, p. 203-219. 
SPIVAK, Gayatri Chakravorty. Pode o subalterno falar? ALMEIDA, Sandra Regina Goulart; FEITOSA, Marcos Pereira; FEITOSA, André Pereira (Trads.). Belo Horizonte: Editora UFMG, 2014.

ZANELLA, Andréa Vieira. Sobre olhos, olhares e seu processo de (re)produção. In: LENZI, Lúcia Helena Correa et alii. (Org.). Imagem: intervenção e pesquisa. Florianópolis: Editora UFSC, 2006. p. 139-149.

Luziane de Assis Ruela Siqueira Universidade Federal do Espírito Santo (UFES)

E-mail: luzianesiq@gmail.com

Luizane Guedes Mateus Universidade Federal do Espírito Santo

E-mail: luizaneguedes@gmail.com

Delani Ferreira dos Santos Graduanda de Psicologia na UFES E-mail: anaclettodelani@gmail.com

Karoline Mendes Santos Graduanda de Psicologia na UFES E-mail: $\underline{\text { lollahsantos@gmail.com }}$

Ketle Silva Mestranda em Psicologia Institucional na UFES E-mail: ketlesilva@hotmail.com

Nayara Oliveira Francisco Mestranda em Psicologia Institucional na UFES E-mail: nayara.oliveira.francisco@gmail.com

\footnotetext{
${ }^{1}$ Reflexões a partir da pesquisa de Pós-doutorado de Luizane Guedes Mateus, uma das autoras do texto, intitulada "As práticas de extermínio no Estado do Espírito Santo e a narrativa de familiares de atingidos pela violência: nossos filhos têm mãe" (pós-doutorado finalizado em 2020).

2 Em alusão à obra de Frantz Fanon, "Os condenados da terra" (FANON, 1961).

${ }^{3}$ Em Navarro et alii. (2020) analisamos como a pandemia vem cronificando a necropolítica, demarcando os quem são marcados para morrer.

${ }^{4}$ Relatos da Pesquisa de Pós-doutorado de Luizane Guedes Mateus.

${ }^{5}$ Homenagem feita por João Bosco a Adir Blanc “Não existe João sem Aldir” (FRAGÃO, 2020).

${ }^{6}$ Pesquisa de Iniciação Científica de Karoline Mendes Santos, cuja proposta era acompanhar mulheres negras gestantes no Hospital Universitário Cassiano Antônio Moraes (HUCAM).

${ }^{7}$ A pedido da autora da carta, o nome escolhido para o filho foi mantido, como uma forma de homenagem.

${ }^{8}$ Desdobramentos de um trabalho realizado no Núcleo de Psicologia Aplicada (NPA) da UFES através de um projeto de Iniciação Científica de Delani Ferreira dos Santos, cujo tema foi "Modos de subjetivação de mulheres negras: as narrativas na clínica psicológica".
} 
9 Daniela é um nome fictício escolhido pela própria paciente para que sua narrativa pudesse ser compartilhada publicamente.

${ }^{10}$ Carta de uma pesquisadora de rastros aos ecos das narrativas costuradas, que excedem este artigo de metodologia. As encruzilhadas dialogam com a pesquisa de mestrado (em andamento) de Nayara Oliveira Francisco, intitulada "Subjetividades transatlânticas, corporeidades exuziáticas: corpo, subjetividade e epistemologias".

${ }^{11}$ Em alusão à canção "Sem nome, mas com endereço", da cantora Liniker e os Caramelows. 